ФЕСЕНКО О.М.

\title{
АДМІНІСТРАТИВНІ ВІДНОСИНИ У СФЕРІ ІНВЕСТУВАННЯ
}

У статті робиться комплексний аналіз сутності адміністративних відносин у сфері інвестування. 3'ясовано, що в даний час в юридичній науці відсутня єдність поглядів на поняття і сутність інвестиційних правовідносин у цілому. Інвестиційні правовідносини як економіко-правове поняття має складну юридичну природу. В юридичній літературі під час розгляду інвестиційних правовідносин представляється можливим виділити два підходи до визначення їхньої сутності: широкий (комплексний) і вузький. Визначено, що адміністративно-правові відносини дуже тісно пов'язані з адміністративно-правовими нормами, а оскільки адміністративно-правові норми регулюють суспільні відносини, які виникають, змінюються і припиняються у сфері діяльності виконавчої влади (державного управління), то вони мають публічний характер та пов'язані зі здійсненням суб'єктами публічної влади їхніх владних повноважень, насамперед під час здійснення виконавчої та розпорядчої діяльності. Отже, ці відносини виникають, змінюються або припиняються тільки на основі адміністративно-правових норм, які породжують дані відносини й реалізуються через них. Зроблено висновок, що інвестиційні правовідносини слід розглядати в рамках «широкого» підходу, який дозволить врівноважити публічно-правову та приватноправову складові частини інституту правового регулювання інвестиційної діяльності держави. Саме комплексний підхід дозволяє виявити три групи інвестиційних правовідносин: інвестиційні правовідносини, що виникають під час здійснення інвестиційної діяльності фізичними та юридичними особами, тобто приватні інвестиції; інвестиційні правовідносини, що виникають під час здійснення інвестиційної діяльності державою та муніципальними утвореннями, тобто публічні інвестиції; інвестиційні правовідносини, пов'язані зі створенням сприятливих умов для розвитку інвестиційної діяльності. Виділення цих груп правовідносин дозволяє розділити сфери публічно-правового й приватноправового регулювання. Так, перша група інвестиційних відносин переважно $\epsilon$ предметом правового регулювання цивільного права, друга група - предметом фінансового права, та третя група - предметом фінансового, адміністративного та міжнародного права.

Ключові слова: інвестииї̈, інвестиційна діяльність, інвестування, адміністративні відносини.

The article provides a comprehensive analysis of the nature of administrative relations in the field of investment. It is found that at present there is no consensus in the legal science on the concept and essence of investment legal relations as a whole. Investment relations as an economic and legal concept have a complex legal nature. In the legal literature when considering investment relationships, it is possible to distinguish two approaches to determining their essence: broad (complex) and narrow. It is determined that the administrative-legal relations are very closely connected with the administrative-legal norms, and since the administrative-legal norms regulate the social relations that arise, change and terminate in the sphere of activity of the executive power (state administration), they have a public character and related to the exercise of public authority by their public authorities, first of all, in the performance of executive and administrative activities. Consequently, these relationships arise, change or terminate only on the basis of the administrative and legal rules that give rise to these relationships and are implemented through them. It is concluded that investment legal relations should

\footnotetext{
(C) ФЕСЕНКО О.М. - кандидат юридичних наук, докторант (Науково-дослідний інститут публічного права)
} 
be considered within the framework of a "broad" approach, which will allow to balance the public-legal and private-law components of the institute of legal regulation of the state's investment activity. It is a complex approach that identifies three groups of investment relationships: investment relationships arising from the implementation of investment activities by individuals and legal entities, ie private investment; investment legal relations arising from the implementation of investment activities by the state and municipal entities, ie public investments; investment relationships related to the creation of favorable conditions for the development of investment activities. Allocation of these groups of relations allows to divide the spheres of public-legal and private-legal regulation. Thus, the first group of investment relations is mainly the subject of legal regulation of civil law, the second group is the subject of financial law and the third group is the subject of financial, administrative and international law.

Key words: investments, investment activity, investing, administrative relations.

Вступ. У сучасних умовах у зв'язку зі зміною змісту та масштабів фінансової діяльності держави виникає необхідність у дослідженні питань, пов'язаних з особливостями адміністративних правовідносин у сфері інвестування.

Аналіз останніх досліджень і публікацій. Дослідженню питань адміністративних відносин, зокрема й у сфері інвестування, в різний час були присвячені роботи О. Харитонової, В. Столбового, І. Голосніченко, Л. Коваля, О. Якуби, В. Колпакова, Ф. Маркелова, Е. Горохова та ін., однак залишається низка питань, які потребують наукового вирішення та вдосконалення.

Постановка завдання. Мета статті полягає в комплексному дослідженні адміністративних відносин у сфері інвестування.

Результати дослідження. Правила формальної логіки говорять, що якщо деяка властивість притаманна певному класу предметів, то вона буде притаманна будь-якому предмету або групі предметів цього класу. Тому видається, що найбільш раціональним підходом до дослідження адміністративних правовідносин у сфері інвестування є підхід, заснований на веденні дослідження від загального до приватного, тобто від юридичних відносин до адміністративних правовідносин, і потім - до їх приватного випадку - інвестиційних правовідносин у сфері інвестиційної діяльності держави.

В юридичній літературі питання про поняття правовідносин відноситься до числа дискусійних, оскільки це одна із центральних правових категорій, що виходить безпосередньо на філософський рівень аналізу. Так, у філософії правові відносини розуміються як один із різновидів суспільних відносин, тому дослідження їхньої суспільної природи в основному полягає у виявленні ступеня відповідності сформованих в юриспруденції ознак правового відношення ознаками і властивостями відносин суспільних.

У загальній теорії права та філософії права поняття і сутність «правовідносин» зумовлені типом праворозуміння, оскільки «відсутність єдиного підходу до розуміння права неминуче тягне за собою різні уявлення про сутність правовідносин» [1, с. 207].

Питання правових відносин завжди викликали великий інтерес і найбільші суперечки в юридичній науці. Можна 3 упевненістю констатувати той факт, що проблема правових відносин $€$ центральною в загальній теорії права. Якщо звернутися до довідкових юридичних видань, можна сказати, що правовідносини - це врегульоване нормами права суспільні відносини, учасники якого є носіями суб'єктивних прав і обов'язків. «Правові відносини - індивідуалізовані відносини, тобто відношення між окремими особами (громадянами, організаціями, державними органами та громадянами тощо), пов'язаними між собою правами та обов'язками, що визначають забезпечену законом міру можливої й належної поведінки» [2, с. 2478].

Як видно, правові відносини - це, перш за все, відносини у зв'язку з правом і на основі права. Вони виникають разом із природними правами та обов'язками, а 3 появою держави найважливіші з них отримують законодавче оформлення. Якщо проаналізувати сутнісні аспекти правовідносин, представлені теоретиками права і держави, можна виділити такі ознаки: це відносини між людьми, пов’язані з їхньою діяльністю і поведінкою; це «законовідношення» [3, с. 196], бо воно виникає, як правило, внаслідок впливу норми права на поведінку людей; це відносини, засновані на зв'язку між людьми, що виникає за допомогою суб'єктивних прав та юридичних обов'язків; це вольові відносини, оскільки для їх виникнення необхідна воля учасників; ці відносини завжди охороняються державою. 
Перераховані характерні риси правовідносини властиві суспільним відносинам, врегульованим нормами права, що відносяться до будь-яких галузей правової системи і сфер законодавства. Звідси можна зробити висновок, що перераховані вище ознаки правовідносин характерні і для адміністративно-правових відносин. Разом із тим адміністративно-правові відносини не були б такими, якби вони не мали свої, характерні тільки для них, відмінні риси. Розглянемо ці особливості. Безумовно, найяскравішою відмінною рисою розглянутих відносин $є$ їхній управлінський характер, оскільки вони виникають у сфері державного регулювання та управління в різних галузях життя суспільства: економічній, політичній, соціально-культурній.

Адміністративно-правові відносини дуже тісно пов'язані з адміністративно-правовими нормами, а оскільки адміністративно-правові норми регулюють суспільні відносини, які виникають, змінюються і припиняються у сфері діяльності виконавчої влади (державного управління), то вони мають публічний характер та пов'язані зі здійсненням суб'єктами публічної влади їхніх владних повноважень, насамперед, під час здійснення виконавчої та розпорядчої діяльності. Отже, ці відносини виникають, змінюються або припиняються тільки на основі адміністративно-правових норм, які породжують дані відносини й реалізуються через них.

Адміністративно-правові відносини носять вольовий характер, оскільки управління в адміністративно-правових відносинах завжди передбачає підпорядкування волі учасників спільної діяльності єдиній керуючій волі. Адміністративно-правові відносини є відносинами «влади-підпорядкування». Як правило, в таких відносинах відсутня рівність сторін, оскільки вони проявляються найчастіше у вертикальній площині, в якій існують субординаційні відносини та сувора підконтрольність нижчестоящих органів вищестоящим. Такі відносини іменуються вертикальними адміністративно-правовими відносинами.

Однак буде не зовсім справедливим підхід, що зводить адміністративно-правові відносини тільки до рівня підпорядковувано-примусових відносин. Науці адміністративного права відомі також відносини, засновані на узгодженні, координації, домовленості тощо, тобто такі адміністративно-правові відносини, які виникають між суб'єктами управлінських відносин, які не перебувають в організаційній підпорядкованості один у одного. Такі відносини, хоч їхній масштаб і значно менше «підрядних» відносин, існують у горизонтальній площині та носять назву горизонтальних адміністративно-правових відносин.

Розглянуті правовідносини не були б такими, якби вони не охоронялися державою за допомогою адміністративної відповідальності. Така державна «опіка» зумовлена, насамперед, тим, що, управлінська діяльність виражає волю та інтереси держави, оскільки в адміністративно-правових відносинах завжди однією зі сторін виступає офіційний суб'єкт виконавчої влади. Незважаючи на те, що в цих відносинах практично можуть брати участь різні сторони, в них завжди $\epsilon$ обов'язкова сторона, без якої такі відносини взагалі не можуть виникнути.

Деякі автори $[4$, с. $120 ; 5$, с. 28$]$ виділяють як особливість адміністративно-правового відносини позасудовий порядок вирішення спорів між його сторонами. Це означає, що основний спосіб вирішення таких спорів не виходить за рамки сфери державного управління. Однак із таким положенням можна погодитися тільки в тому випадку, якщо спір виникає всередині адміністративного органу, наприклад, між відділами, управліннями, кафедрами, відомствами і т.п. Якщо ж учасниками адміністративних правовідносин, що породили адміністративний спір, виступають, наприклад, фізична особа та адміністрація будь-якого органу (підприємство, установа, мерія міста тощо), то такі суперечки вирішуються в судовому порядку на основі Закону України від 02.10.1996 року № 393/96-ВР «Про звернення громадян».

Охарактеризувавши основні відмінні риси та визначивши місце адміністративно-правових відносин у системі правовідносин, перейдемо до визначення їхніх понять. Хочеться зауважити, що практично всі вчені-адміністративісти займалися та займаються в даний час дослідженням адміністративно-правових відносин, оскільки дані відносини є ключовими, вузловими, всередині яких народжуються, існують, видозмінюються та припиняються різноманітні взаємини і зв'язки, що складаються в області адміністративного права. Щодо поняття адміністративно-правових відносин, то у своєму монографічному дослідженні О.А. Харитонова зазначала, що адміністративно-правові відносини є урегульованими адміністративно-правовою нормою суспільними відносинами, що складаються в галузі державного управління та адміністративної охорони публічного правопорядку, один із учасників або всі учасники яких є носіями владних повноважень, а також суб'єктивних прав та юридичних обов'язків, які перебувають під охороною держави [6, с. 161]. І.П. Голосніченко зазначає, що адміністративно-правові відносини є системою прав та обов'язків органів державної виконавчої влади, посадових осіб і службовців, громадян та інших суб'єктів 
[7, с. 9]. Л.В. Коваль свого часу писав, що предметом адміністративного права є суспільні відносини, які виникають під час здійснення державного управління [8, с. 6]. О.М. Якуба вважала, що адміністративно-правові відносини - це суспільні відносини, що регулюються адміністративно-правовими нормами, в яких одна із сторін наділена правом вимагати від іншої сторони у процесі виконавчої та розпорядчої діяльності дотримання поведінки, вказаної в адміністративно-правовій нормі, а також це відношення охороняється державою [9, с. 53]. На нашу думку, слушним є зауваження В.К. Колпакова, що поняття адміністративно-правових відносин стає все ширшим і виходить за межі державного управління. Про це свідчить їх висвітлення в навчальній літературі [10, с. 101].

Таким чином, ураховуючи особливості, а також виходячи з наявних розробок визначень, що стосуються правової сутності адміністративних правовідносин, сформулюємо таке визначення адміністративно-правових відносин: це врегульовані адміністративно-правовою нормою, що охороняється адміністративною відповідальністю, управлінські відносини, учасники яких, виявляючи волевиявлення, утворюють між собою зв'язок, за допомогою юридичних прав і обов'язків та вирішують адміністративні спори, як у судовому, так і в позасудовому порядку.

Ми вважаємо, що під адміністративно-правовими відносинами у сфері інвестування слід розуміти врегульовані нормами адміністративного права суспільні відносини, які складаються у сфері інвестування, коли один із суб'єктів інвестиційної діяльності або всі суб'єкти інвестиційної діяльності $є$ носіями владних повноважень та перебувають під захистом (охороною) держави.

Для адміністративно-правових відносин характерні такі елементи: генетичний, формальний і функціональний. Кожний із них має індивідуальні особливості, які проявляються через взаємодію, реалізацію за допомогою певних способів чи зв'язків із метою реалізації прав і обов'язків учасників відносин [11, с. 71]. Вказані елементи та особливості адміністративно-правових відносин впливають на формування загальних рис, які властиві всім правовідносинам. Зокрема, це стосується: урегульованості суспільних відносин нормами права; наявності вольового впливу норм права на суспільні відносини; наявності суб'єктивних прав та юридичних обов'язків для учасників правовідносин.

На основі вищезазначеного до основних ознак адміністративно-правових відносин у сфері інвестування слід віднести:

- права та обов'язки сторін, пов'язані з виконавчою і розпорядчою діяльністю держави та місцевого самоврядування; тивної влади;

- в адміністративно-правових відносинах однією із сторін завжди є суб'єкт адміністра-

- порушення адміністративно-правової норми у сфері інвестування спричиняє відповідальність порушника перед державою;

- адміністративно-правові відносини є владними відношеннями, побудованими на засадах «влада-підпорядкування»;

- адміністративно-правові відносини у сфері інвестування за своєю сутністю є різновидом організаційних відносин, які відображають публічно правовий і державний інтерес, що виникає за ініціативою будь-якого учасника цих відносин;

- спори, що виникають під час порушення адміністративно-правових відносин у сфері інвестування, вирішуються в адміністративному та судовому порядку;

- наявність конкретного суспільного зв'язку у сфері інвестування врегульованого адміністративно-правовою нормою;

- можливість державного примусу в умовах необхідності його застосування до учасників адміністративно-правових відносин;

- виникнення відносин на підставі й основі адміністративно-правових норм;

- здійснення адміністративно-правових відносин між суб'єктами відбувається на вольовій основі, свідомо та цілеспрямовано.

У даний час в юридичній науці відсутня єдність поглядів на поняття і сутність інвестиційних правовідносин у цілому. Інвестиційні правовідносини як економіко-правове поняття має складну юридичну природу. В юридичній літературі під час розгляду інвестиційних правовідносин представляється можливим виділити два підходи до визначення їхньої сутності: широкий (комплексний) і вузький.

Такий порядок речей випливає з того, що правове регулювання інвестиційних відносин складається із двох частин:

1. Національно-правове (публічно-правове (норми конституційного, адміністративного права) та приватноправове (норми цивільного права). 
2. Міжнародно-правове (публічно-правове (норми міжнародного публічного права, точніше - його інституту-міжнародного економічного права) та приватноправове (норми міжнародного приватного права) [12, с. 107].

У зв'язку із цим рух капіталів (внутрішніх інвестицій) тієї чи іншої держави регулюється правовими нормами даної держави (національно-правове регулювання (внутрішнє інвестиційне законодавство). Рух капіталів (зовнішніх інвестицій, іноземних інвестицій) поза рамками однієї держави регулюється як нормами міжнародного публічного права, так і нормами міжнародного приватного права. Унаслідок цього можна констатувати, що міжнародно-правове регулювання інвестиційних відносин здійснюється за допомогою правових норм, як міжнародного публічного права, так і міжнародного приватного право.

Із точки зору «вузького» підходу інвестиційні правовідносини можуть бути ототожнені або тільки $з$ публічними, або із приватними правовідносинами. Е.А. Горохов розглядає інвестиційні правовідносини з точки публічного права, вважаючи їх однією з форм (видів) фінансових відносин, які характеризуються змішаною, майново-організаційною сутністю [13, с. 20]. Є.Ю. Грачова та Д.М. Щекін відзначають, що публічні інвестиційні відносини є предметом правового регулювання фінансового права [14, с. 766].

Із позиції «широкого» (комплексного) підходу інвестиційні правовідносини являють собою сукупність публічно-правових і приватноправових відносин, що виникають у сфері інвестиційної діяльності. Із цього приводу Ф.В. Маркелов зазначає, що інвестиційні відносини можна одночасно характеризувати як із приватноправових, так і з публічно-правових позицій. Предметом цивільного права є суспільні економічні відносини, пов'язані із вкладенням капіталу, в яких беруть участь тільки «приватні» господарюючі суб'єкти. До публічних же ознак інвестиційних відносин він відносить такі: - участь у них публічно-правових утворень, які, з одного боку, встановлюють «правила поведінки» для учасників інвестиційних відносин, а, з іншого боку, самі виступають активними їх учасниками; - використання бюджетів різних рівнів бюджетної системи; зв'язок інвестиційних відносин з оподаткуванням; - зв'язок інвестиційних відносин із розвитком грошової системи держави і вдосконаленням механізмів кредитування (руху позичкового капіталу); - набуття спеціального статусу інвестора, пов'язаного $з$ додатковими правами та гарантіями, більш пільговим режимом господарської діяльності, тільки в галузях публічного права [15, с. 32].

Думається, що в широкому розумінні інвестиційні правовідносини мають бути визначені як «сукупність правових норм публічно-правового та приватноправового характерів, що регулюють інвестиційні відносини, що виникають із здійснення інвестиційної діяльності, як на національному, так і на міжнародному рівні».

Висновки. Аналіз вищевикладеного дозволяе зробити висновок, що інвестиційні правовідносини слід розглядати в рамках «широкого» підходу, який дозволить врівноважити публічно-правову та приватноправову складові частини інституту правового регулювання інвестиційної діяльності держави. Саме комплексний підхід дозволяє виявити три групи інвестиційних правовідносини:

1) інвестиційні правовідносини, що виникають під час здійснення інвестиційної діяльності фізичними та юридичними особами, тобто приватні інвестиції;

2) інвестиційні правовідносини, що виникають під час здійснення інвестиційної діяльності державою та муніципальними утвореннями, тобто публічні інвестиції;

3) інвестиційні правовідносини, пов’язані зі створенням сприятливих умов для розвитку інвестиційної діяльності.

Виділення цих груп правовідносин дозволяє розділити сфери публічно-правового й приватноправового регулювання. Так, перша група інвестиційних відносин переважно $є$ предметом правового регулювання цивільного права, друга група - предметом фінансового права, та третя група - предметом фінансового, адміністративного та міжнародного права.

Звідси виходить, що в інвестиційних правовідносинах важлива динаміка - тобто без будьяких прагнень здійснення інвестиційної діяльності не виникнуть відповідні інвестиційні правовідносини, а значить, вони опосередковують правове регулювання інвестиційної діяльності. Отже, можна констатувати, що особливістю інвестиційних правовідносин $є$ комплексний характер їхніх норм, зібраних воєдино, і які представляють різні галузі права.

Список використаних джерел:

Загальна теорія держави і права : підручник для студентів юридичних вищих навчальних закладів / М.В. Цвік, О.В. Петришин, Л.В. Авраменко та ін. ; за ред. д-ра юрид. наук, проф., 
акад. АПрН України М.В. Цвіка, д-ра юрид. наук, проф., акад. АПрН України О.В. Петришина. Харків : Право, 2009. 584 с.

Юридична енциклопедія: У 6-ти т. / під ред. Ю.С. Шемшученко. Київ : Українська енциклопедія ім. М.П. Бажана, 1998-2004. 4429 с.

Теорія держави та права : навч. посіб. / Є.В. Білозьоров, В.П. Власенко, О.Б. Горова та ін. ; за заг. ред. С.Д. Гусарєва, О.Д. Тихомирова. Київ : НАВС, Освіта України, 2017. 320 с.

Мельник Р.С., Бевзенко В.М. Загальне адміністративне право: Навчальний посібник / За заг. ред. Р.С. Мельника. Київ : Ваіте, 2014. 376 с.

Адміністративне право України. Повний курс : підручник / Галунько В., Діхтієвський П., Кузьменко О., Стеценко С. та ін. Херсон : ОЛДІ-ПЛЮС, 2018. 446 с.

Харитонова О.І. Адміністративно-правові відносини (проблеми теорії) : монографія. Одеса : Юридична література, 2004. 328 с.

Голосніченко І.П. Адміністративне право України (основні категорії і поняття). Київ : МАУП, 1998. $52 \mathrm{c.}$ $154 \mathrm{c}$.

Коваль Л.В. Адміністративне право України [Текст] : Курс лекцій. Київ : Основи, 1994.

Якуба О.М. Административная ответственность. Москва : Юрид. лит., 1972. 152 с.

Колпаков В.К. Адміністративно-правові відносини: поняття і види. Юридичний науковий електронний журнал. 2013. № 1. C. 102-104. URL : http://www.lsej.org.ua/1_2013/ukr/Kolpakov. pdf (дата звернення: 23.09.2019).

Сопільник Л.І. Стандартизація, якість продукції, метрологія, сертифікація в системі адміністративного права : навчальний посібник. Львів : Львівський університет бізнесу та права, 2011. $124 \mathrm{c}$.

Гущин В.В. Инвестиционное право : учебник. Москва : Эксмо, 2009. 623 с.

Горохов Е.А. Правовое обеспечение инвестиционной деятельности в Российской Федерации (финансово-правовой аспект) : дис. ... канд. юрид. наук : 12.00.14. Москва, 2005. 167 с.

Грачева Е.Ю., Щекин Д.М. Комментарий к диссертационным исследованиям по финансовому праву. Москва : Статут, 2009. 1055 с.

Маркелов Ф.В. Инвестиционные правоотношения. Правовое регулирование инвестииионной деятельности: проблемы и перспективы развили / Е.В. Покачалова, Ф.В. Маркелов, С.В. Журавлева та ін. ; под ред. Е.В. Покачаловой ; ГОУ ВПО «СГАП». Саратов : Изд-во ГОУ ВПО «СГАП», 2009. 238 с. 